\title{
Cell Calcium Levels of Normal and Cystic Fibrosis Nasal Epithelium
}

\author{
ELIZABETH MURPHY, ELAINE CHENG, JAMES YANKASKAS, M. JACKSON STUTTS, AND \\ RICHARD C. BOUCHER
}

\author{
National Institute of Environmental Health Sciences, Laboratory of Molecular Biophysics, Research Triangle \\ Park, North Carolina 27709 and Division of Pulmonary Medicine, School of Medicine, University of North \\ Carolina, Chapel Hill, North Carolina 27514
}

\begin{abstract}
To determine whether epithelial ion transport abnormalities in cystic fibrosis (CF) might reflect abnormal regulation of intracellular $\mathrm{Ca}^{2+}$ levels, cytosolic free calcium $\left(\mathrm{Ca}_{\mathrm{i}}{ }^{2+}\right)$ was measured using fura-2 or quin 2 in suspensions of normal or CF nasal epithelial cells derived from primary cell culture. The basal $\mathrm{Ca}_{i}{ }^{2+}$ level measured with fura-2 in CF nasal epithelia was $155 \pm 9 \mathrm{nM}(n=5)$, a value not significantly different from normal nasal epithelia $(143 \pm 16 \mathrm{nM}, n=5)$. Total cell calcium was measured by atomic absorption spectroscopy and no differences were observed between CF $(6.3 \pm 0.5 \mathrm{nmol} / \mathrm{mg}$ protein; $n=3)$ and normal $(6.2 \pm 1.2 \mathrm{nmol} / \mathrm{mg}$ protein; $n$ $=3$ ) nasal epithelial cells. Placing $\mathrm{Na}^{+}$loaded cells in a low $(10 \mathrm{mM})$ extracellular $\mathrm{Na}^{+}$solution resulted in a rapid increase in $\mathrm{Ca}_{i}{ }^{2+}$ consistent with $\mathrm{Ca}^{2+}$ uptake via a plasmalemmal $\mathrm{Na}^{+}-\mathrm{Ca}^{2+}$ exchanger. The level of $\mathrm{Ca}_{i}{ }^{2+}$ achieved by this low $\mathrm{Na}^{+}$maneuver was not significantly different in CF cells compared to normal cells. Neither isoproterenol $\left(10^{-5} \mathrm{M}\right)$ nor forskolin $\left(1^{-6} \mathrm{M}\right)$ had any effect on $\mathrm{Ca}_{\mathrm{i}}{ }^{2+}$ in normal or $\mathrm{CF}$ nasal epithelial cells. Thus, it appears that differences in cell $\mathrm{Ca}_{i}{ }^{2+}$, as measured by fluorescent chelators in suspensions of cultured cells, do not account for the abnormalities in basal or isoproterenol stimulated ion transport in CF tissues. (Pediatr Res 24: 79-84, 1988)
\end{abstract}

\section{Abbreviations}

$\mathrm{Ca}_{\mathrm{i}}{ }^{2+}$, cytolsolic free calcium

$\mathrm{CF}$, cystic fibrosis

AM, acetoxymethyl ester

TCA, trichloroacetic acid

PMN, polymorphonuclear cells

The pathophysiology of CF appears to reflect abnormal epithelial ion transport functions in specific target epithelia $(1,2)$. Recent evidence has focused on the notion that the abnormalities in epithelial ion transport in the lung reflect dysfunctions in regulatory processes rather than abnormalities in the permeability properties of channel proteins. Evidence for this notion has accrued from two lines of investigation. First, studies of freshly excised nasal epithelia have shown that there is 1) an imbalance between the basal rate of $\mathrm{Na}^{+}$absorption and the capacity to secrete $\mathrm{Cl}^{-}$in $\mathrm{CF}$ as compared to normal tissues (3); and 2) the response to $\beta$-adrenergic agonists qualitatively differs in the two preparations, i.e., isoproterenol induces $\mathrm{Cl}^{-}$secretion in normal

Received September 17, 1986; accepted March 3, 1988.

Correspondence and reprint requests Elizabeth Murphy, Laboratory of Molecular Biophysics, NIEHS, P.O. BOX 12233, Research Triangle Park, NC 27709. tissues whereas $\mathrm{Na}^{+}$absorption is accelerated in CF tissues (4). Second, evidence from patch clamp studies of cultured tracheal epithelial cells indicate that the conductive properties of $\mathrm{Cl}^{-}$ channels from $\mathrm{CF}$ patients are not different from normal patients when the patches are excised from the cell, implying a defect of cellular control of channel activation $(5,6)$.

Because regulation of many cellular functions, including both $\mathrm{Na}^{+}$and $\mathrm{Cl}^{-}$transport, may be linked to changes in cell calcium $(7,8)$, total cell calcium and $\mathrm{Ca}_{\mathrm{i}}{ }^{2+}$ have been measured in a number of nonepithelial cell types from normal and $\mathrm{CF}$ patients. The results of studies of cultured fibroblasts and circulating blood elements are contradictory and have not been correlated with specific ion transport defects $(9-15) . \mathrm{Ca}_{i}{ }^{2+}$ or total cell calcium have not been measured in target epithelia from patients with this disease.

Herein we have measured $\mathrm{Ca}_{\mathrm{i}}{ }^{2+}$ with fluorescent chelators in suspensions of normal and cystic fibrosis nasal epithelial cells grown in culture. Basal $\mathrm{Ca}_{\mathrm{i}}{ }^{2+}$ levels were measured and the presence of a $\mathrm{Na}^{+}-\mathrm{Ca}^{3+}$ exchange process, and responses to selected pharmacologic agonists were tested. Cultured nasal cells were chosen for study because of their availability and because the $\mathrm{Cl}^{-}$permeability defect that characterizes $\mathrm{CF}$ has been reported to be retained in this preparation (16).

\section{MATERIALS AND METHODS}

Tissues and subjects. All tissues were obtained from patients undergoing clinically indicated surgery, through an arrangement approved by the Human Rights Committee for the School of Medicine at the University of North Carolina at Chapel Hill. CF subjects were diagnosed by standard clinical and sweat electrolyte criteria and required excision of nasal polyps to relieve obstruction. There were nine males and five females, age $16.3 \pm 2.4 \mathrm{yr}$ (range 8 to $38 \mathrm{yr}$ ). Normal nasal tissue was inferior turbinate that was removed during reconstructive procedures. The patients were 12 males and four females, age $34.0 \pm 3.9$ yr (range 7 to 69 yr). Some CF and non-CF patients had received medications chronically, e.g. antibiotics and inhaled steroids, but these were usually discontinued 7 to 14 days before surgery.

Cell isolation and culture. The culture conditions were described in detail by Wu et al. (17). Freshly excised polyp or nasal turbinate mucosa was rinsed and incubated in sterile Joklik's modified Eagle medium with $0.1 \%$ protease (Sigma Chemical Co., St. Louis, MO, type 14$)$, penicillin $(60 \mathrm{U} / \mathrm{ml})$, streptomycin $(60 \mu \mathrm{g} / \mathrm{ml})$, and gentamicin $(50 \mu \mathrm{g} / \mathrm{ml})$. The tissue and medium were maintained at $4^{\circ} \mathrm{C}$ for 36 to $48 \mathrm{~h}$ with periodic gentle agitation. For tissues obtained from distant CF centers, this period included transit via commercial carriers. Fetal bovine serum $(10 \%)$ was added to neutralize the protease, and the resulting suspension of epithelial cells was passed through nylon mesh to remove clumps and debris. The cells (ciliated, mucous, 
and basal) were centrifuged $(500 \times g, 5 \mathrm{~min})$ and resuspended in protease-free medium twice. Washed cells were plated on plastic tissue culture dishes (Falcon Labware, Oxnard, CA) at a density of 2 to $3 \times 10^{4}$ cells $/ \mathrm{cm}^{2}$ in serum-free, growth factor supplemented Ham's F12 medium (17). The cells were incubated at $37^{\circ} \mathrm{C}$ in a humidified $5 \% \mathrm{CO}_{2}: 95 \%$ air atmosphere. Cells not attached to the culture dish (attachment efficiency was 20-30\%) were removed after $24 \mathrm{~h}$ by replacement of the medium with fresh supplemented F12. The cells were grown for another 1421 days. The medium was changed three times per week. Four to 11 days before use, at about $70 \%$ confluency, the growth medium was changed to a 1:1 mixture of supplemented F12 medium and Dulbecco's modified Eagle medium conditioned by exposure to $\mathrm{NIH} / 3 \mathrm{~T} 3$ fibroblasts (17). Conditioned medium contained $1 \%$ fetal bovine serum and appeared to further increase cell density at confluence.

Fluorescence measurement of $\mathrm{Ca}_{i} . \mathrm{Ca}_{\mathrm{i}}{ }^{2+}$ was measured with the fluorescent dyes quin 2 or fura-2, as described by Tsien and coworkers (18-20). The nasal epithelial cells from five $60-\mathrm{mm}$ culture dishes $\left(3 \times 10^{5}\right.$ cells/dish) were removed by a brief $(6-$ min) exposure to $0.1 \%$ trypsin in a $\mathrm{Ca}^{2+}$-free solution. The cells were then centrifuged and resuspended in a modified Hanks' HEPES solution containing in mM: $\mathrm{NaCl}, 120 ; \mathrm{K}_{2} \mathrm{HPO}_{4}, 1.2$; $\mathrm{MgSO}_{4}, 1.2 ; \mathrm{KCl}, 5$; glucose, 10 ; sodium HEPES, $10 ; \mathrm{CaCl}_{2}$, 1.25. The cells were allowed to reequilibrate in this solution for 30 min after which they were loaded with the AM of the calcium indicator by incubating them at $10^{6}$ cells $/ \mathrm{ml}$ for $20 \mathrm{~min}$ at $37^{\circ} \mathrm{C}$ with either quin2-AM (50 $\mu \mathrm{M}$; Calbiochem-Behring, La Jolla, CA) or fura-2-AM ( $1 \mu \mathrm{M}$; Molecular Probes, Eugene, OR). After loading, the cells were washed twice with modified Hanks'HEPES and resuspended in the same solution. Fluorescent measurements of quin 2 and fura- 2 were made on an Aminco spectroflurometer (model SPF-500, Aminco, Silver Spring, MD) with excitation at $340 \mathrm{~nm}$ and emission at $510 \mathrm{~nm}$.

Quin 2 measurements. The quin 2 loaded cells $\left(\sim 3 \times 10^{5}\right.$ cells/ $3 \mathrm{ml})$ were placed in a stirred water-jacketed cuvette $\left(37^{\circ} \mathrm{C}\right) . \mathrm{Ca}_{i}$ was measured using the method described by Tsien et al. (19), modified slightly to allow correction for extracellular dye (21, 22). Two methods have been described for correcting for extracellular dye $(22,23)$; a correction using $\mathrm{Mn}^{2+}$ or EGTA. As described below, our experiments with quin2-loaded cells were designed to allow a comparison of both methods of correcting for extracellular dye.

Mn correction. After obtaining a baseline fluorescence ( $\mathrm{F} 1), 5$ $\mu \mathrm{M} \mathrm{MnCl}{ }_{2}$ were added to reduce the fluorescence of extracellular quin 2 in $1.25 \mathrm{mM} \mathrm{CaCl}_{2}$ by $0.5(\mathrm{~F} 2)$. Excess EGTA $(2 \mathrm{mM})$ plus tris hydroxymethylaminomethane $(\mathrm{pH} 8.1)$ were added to obtain F3. The $2 \mathrm{mM}$ EGTA binds the $5 \mu \mathrm{M} \mathrm{Mn^{2+ }}$ allowing an independent measure of extracellular dye, as well as measurement of $F_{\max }$ and $F_{\min }$ without interference from $\mathrm{Mn}$. Digitonin $(70 \mu \mathrm{g} / \mathrm{ml})$ was then added to obtain the fluorescence of quin 2 in the absence of $\mathrm{Ca}^{2+}(\mathrm{F} 4)$. Saturating levels of $\mathrm{CaCl}_{2}(10 \mathrm{mM})$ were then added to obtain F5. Ca $a_{i}$ was then calculated using the equation described by Tsien et al. (19).

$$
\mathrm{Ca}_{\mathrm{i}}=\mathrm{K}_{\mathrm{D}} *\left(\mathrm{~F}-\mathrm{F}_{\min }\right) /\left(\mathrm{F}_{\max }-\mathrm{F}\right)
$$

In this equation $\mathrm{K}_{\mathrm{D}}$, the quin2 dissociation constant is $115 \mathrm{nM}$ (19). $F$ is the initial level of fluorescence, $F_{\max }$ is the fluorescence with saturating $\mathrm{Ca}^{2+}$, and $\mathrm{F}_{\min }$ is the fluorescence in the presence of excess EGTA. To correct the variables $F, F_{\max }$ and $F_{\min }$ for the presence of extracellular quin2, we have subtracted from $F$, $F_{\max }$, and $F_{\min }$ the fluorescence due to extracellular dye: $F=F 1$ - $[(\mathrm{F} 1-\mathrm{F} 2) / 0.5] ; \mathrm{F}_{\max }=\mathrm{F} 5-[(\mathrm{F} 1-\mathrm{F} 2) / 0.5] ;$ and $F_{\min }=\mathrm{F} 4-(0.3$ $[(F 1-F 2) / 0.05]) . F_{\min }$ must be corrected because there is a calcium-independent component of quin 2 fluorescence $(30 \%)$, and therefore extracellular dye will also contribute to $\mathrm{F}_{\min } . \mathrm{Mn}^{2+}$ quenches all quin2 fluorescence, both calcium dependent and calcium independent.

Finally, to determine if there were significant levels of uncleaved dye in our cells, we made use of the observation that uncleaved dye has a higher $K_{D}$ for Ca binding than completely hydrolyzed dye $(24,25)$. To test whether the intracellularly generated quin 2 has the same $K_{D}$ as the free acid, we did the following experiment. A Ca-EGTA buffer was prepared and the free- $\mathrm{Ca}^{2+}$ value, determined with commercially produced free acid of quin2 (Molecular Probes), was found to be $288 \mathrm{nM}$. Cells that had been loaded with quin 2 by exposure to the acetoxymethyl ester were then lysed in this solution. The free-Ca level was then determined using the fluorescence of the intracellularly generated quin 2 and was found to be $299 \mathrm{nM}$. These data suggest that the $K_{D}$ for quin 2 generated intracellularly is similar to that of the free acid. Furthermore, our method of calibration automatically circumvents the contribution of uncleaved, $\mathrm{Ca}^{-}$insensitive dye, to the measurement of $\mathrm{Ca}^{2+}$.

$E G T A$ correction. Inasmuch as EGTA has a high affinity for $\mathrm{Mn}$ and EGTA was added after $\mathrm{Mn}$, we can also correct for extracellular dye by using the difference between the fluorescence before and after EGTA (F1-F3). Thus, we can compare these two methods for correction in each experiment. F1 through F5 are defined as in the $\mathrm{Mn}$ correction, and $\mathrm{Ca}_{\mathrm{i}}{ }^{2+}$ is calculated from equation 1 with $F_{\max }$ and $F$ corrected for extracellular dye as follows: $F_{\max }=F 5$ - (F1-F3), F = F1 - (F1-F3). $F_{\min }\left(F_{\min }=F 4\right)$ does not need to be corrected because unlike Mn, EGTA does not quench $\mathrm{Ca}$-independent fluorescence.

We found that estimates of extracellular dye and calculated $\mathrm{Ca}_{\mathrm{i}}$ levels corrected with $\mathrm{Mn}^{2+}$ and EGTA agreed within $10 \%$. Further, there were no systematic differences in the two methods of correction. Extracellular dye was corrected for in each experiment.

Dye loading was calculated from the difference between $F_{\max }$ and $F_{\min }$ compared to an addition of a known concentration of quin2. Intracellular quin2 concentrations were $\sim 6.4 \mathrm{nmol} / 10^{6}$ cells.

Fura- 2 measurements. These measurements were similar to those for quin2-loaded cells with the only difference being that we used only the EGTA addition to correct for extracellular dye. $A K_{D}$ of $224 \mathrm{nM}$ was used for fura-2 (20). Intracellular fura-2 concentrations were $\sim 0.6 \mathrm{nmol} / 10^{6}$ cells.

Measurement of total cell calcium. Total cell calcium was measured as described in detail elsewhere (21). Briefly, the cells on the culture dish were washed three times with an ice-cold calcium-free buffer. After this the calcium was extracted with 1 $\mathrm{N} \mathrm{HNO}_{3}$. Aliquots of the $\mathrm{HNO}_{3}$ were taken, diluted with a calcium blank solution, and the samples were read with standards on an atomic absorption spectrometer. The remaining $\mathrm{HNO}_{3}$ was removed from the dish and $0.6 \mathrm{~N} \mathrm{NaOH}$ was added to dissolve the cell protein, following which protein was measured by the procedure of Lowry et al. (26).

Protocols. Initial experiments were performed to estimate the rate of dye leakage over intervals that spanned those of experimental protocols. The rate of dye leakage was found to be negligible. Consequently, the fluorescence before addition of the hormone (or other agent) served as the baseline for each experiment's manipulation. In addition, a control measurement of $\mathrm{Ca}_{\mathrm{i}}$ was made on each aliquot of cells.

Cells were preincubated in a stirred, thermostated $\left(37^{\circ} \mathrm{C}\right)$ cuvette for $10 \mathrm{~min}$. For most experiments the appropriate drug or vehicle was then added and the fluorescence was monitored for an additional $10 \mathrm{~min}$. This sequence was followed by calibration of $\mathrm{Ca}_{i}{ }^{2+}$ (see Fig. 1). Experiments designed to test for the presence of a $\mathrm{Na}^{+}-\mathrm{Ca}^{2+}$ exchanger had a slightly different protocol. For this series of experiments, a stock cell suspension was preincubated in a shaker bath at $37^{\circ} \mathrm{C}$ at $15 \times$ the normal concentration. At $t=0,200 \mu \mathrm{l}$ of the cell suspension were diluted into $3 \mathrm{ml}$ Hanks'-HEPES buffer in the cuvette (1:15 dilution), the basal fluorescence was noted, and $10^{-4} \mathrm{M}$ ouabain was then added to both the cells in the cuvette and the stock cell suspension. After a 10-min incubation, the $\mathrm{Ca}^{2+}$ level of the cells in the cuvette was measured by calibration with EGTA and Tris base, digitonin, and excess $\mathrm{Ca}^{2+}$. Also after $10 \mathrm{~min}$ exposure to ouabain $\left(10^{-4} \mathrm{M}\right), 200 \mu \mathrm{l}$ of the stock cell suspension were diluted into 3 

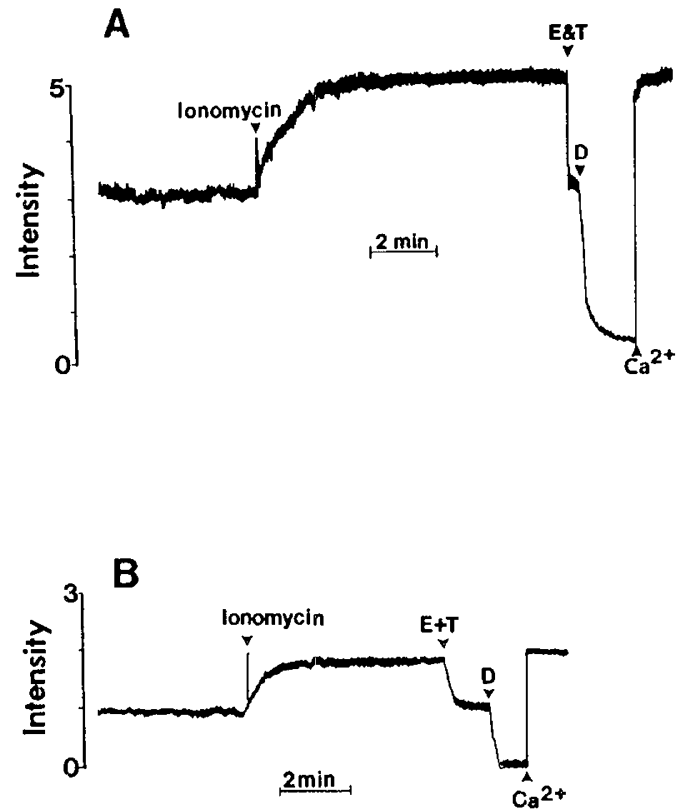

Fig. 1. Effect of ionomycin $\left(10^{-5} \mathrm{M}\right)$ on $\mathrm{Ca}_{\mathrm{i}}{ }^{2+}$ in fura-2-loaded nasal epithelial cells. $A$ depicts the fluorescence intensity and changes in intensity (excitation $340 \mathrm{~nm}$; emission $510 \mathrm{~nm}$ ) from a cell suspension from a normal subject. $B$ is the fluorescence intensity and changes in intensity as a function of added reagents in a cell suspension from a $\mathrm{CF}$ patient. $E \& T, 2 \mathrm{mM}$ EGTA plus Tris base $(\mathrm{pH}=8.1) ; D, 70 \mu \mathrm{g} / \mathrm{ml}$ of digitonin; $\mathrm{Ca}^{2+}, 10 \mathrm{mM} \mathrm{CaCl}_{2}$.

$\mathrm{ml}$ of $\mathrm{Na}^{+}$-free Hanks'-HEPES buffer (choline chloride substituted; final concentration $\mathrm{Na}_{\mathrm{o}}{ }^{+}=10 \mathrm{~mm}$ ), and $\mathrm{Ca}_{\mathrm{i}}{ }^{2+}$ was measured.

Measurements of $c A M P$. Cells were removed from dishes by trypsinization as described above. The cells were washed, resuspended in Hanks'-HEPES solution, and allowed to equilibrate for $60 \mathrm{~min}$ at $37^{\circ} \mathrm{C}$ in a $100 \% \mathrm{O}_{2}$ atmosphere. Aliquots of cells $\left(3 \times 10^{5}\right)$ were exposed to vehicle (basal values) or to isoproterenol $\left(10^{-5} \mathrm{M}\right)$ for 2 and $10 \mathrm{~min}$ after which the cells were pelleted $(600 \times g, 10 \mathrm{~min})$ and the cAMP content of a TCA $(10 \%)$ extract measured as previously described (4). The TCA-precipitated pellet was solubilized in $0.5 \mathrm{M} \mathrm{NaOH}$ solution and protein measured as described previously by the Bradford technique with bovine serum albumin as a standard (4). Each time point for each tissue was measured in triplicate, the results averaged, and expressed as $\mathrm{pmol} / \mathrm{mg}$ protein. Recovery of added cAMP exceeded $90 \%$.

Statistics. All values represent the mean \pm SEM. Comparisons between values obtained with fura- 2 and quin 2 were made using $t$ test for independent means. Comparisons of effects of drugs and low $\mathrm{Na}_{\circ}{ }^{+}$on $\mathrm{Ca}_{\mathrm{i}}{ }^{2+}$ were made with $t$ tests for paired samples.

\section{RESULTS}

Table 1 shows basal $\mathrm{Ca}_{\mathrm{i}}{ }^{2+}$ levels measured with quin2 and fura-2 in nasal epithelial cells from normal subjects and $\mathrm{CF}$ patients. There is no significant difference in basal $\mathrm{Ca}_{\mathrm{i}}{ }^{2+}$ levels between normal and CF cells measured with either quin2 $(p>$ $0.2)$ or fura- $2(p>0.2)$. However, the levels of $\mathrm{Ca}_{\mathrm{i}}{ }^{2+}$ measured with fura-2 were significantly higher than those measured with quin2. The total cell calcium content in cultured normal and $C F$ nasal epithelial cells were not significantly different $(p>0.2$; Table 1)

To investigate whether the measurement system was sensitive to changes in cell $\mathrm{Ca}_{i}{ }^{2+}$, fura-2-loaded cells were exposed to a $\mathrm{Ca}^{2+}$ ionophore. Figure 1 and Table 2 show that addition of 10 $\mu \mathrm{M}$ ionomycin, a nonfluorescent $\mathrm{Ca}^{2+}$ ionophore, induced increases in $\mathrm{Ca}_{\mathrm{i}}{ }^{2+}$ in both $\mathrm{CF}$ and normal nasal epithelial cells. In both $\mathrm{CF}$ and normals, ionomycin elevated $\mathrm{Ca}_{\mathrm{i}}{ }^{2+}$ to a level that
Table 1. Basal $\mathrm{Ca}^{2+}$ levels and contents of cultured normal and CF nasal epithelia*

\begin{tabular}{cccc}
\hline & & Normal & CF \\
\hline & Quin2 & $81 \pm 16$ & $106 \pm 12$ \\
$\mathrm{Ca}_{\mathrm{i}}{ }^{2+}$ level & & $(n=5)$ & $(n=3)$ \\
$(\mathrm{nM})$ & Fura-2 & $143 \pm 16 \dagger$ & $155 \pm 9 \dagger$ \\
& & $(n=5)$ & $(n=5)$ \\
Total cell Ca & & \\
$(\mathrm{nmol} / \mathrm{mg} \mathrm{protein})$ & & $6.2 \pm 1.2$ & $6.3 \pm 0.5$ \\
& & $(n=3)$ & $(n=6)$ \\
\hline
\end{tabular}

*Values are mean \pm SEM; $n=$ number of separate patient specimens tested.

$\dagger$ Fura- 2 value different than quin2 value $(p<0.05)$.

saturated fura-2. Because fura- 2 is saturated with $\mathrm{Ca}^{2+}$ at approximately $2000 \mathrm{nM}$ activity, we have listed the concentration in Table 2 for ionomycin exposed cells as equal to or more than $2000 \mathrm{nM}$.

We also tested whether basal cell $\mathrm{Ca}_{\mathrm{i}}{ }^{2+}$ levels in fura-2 loaded cells were in part regulated by $\mathrm{Na}^{+}-\mathrm{Ca}^{2+}$ exchange. We reasoned that if a Na${ }^{+}-\mathrm{Ca}^{2+}$ exchanger existed in these cells, we should see a significant elevation in $\mathrm{Ca}_{i}{ }^{2+}$ upon placing sodium-loaded cells (exposed to $10^{-4} \mathrm{M}$ ouabain for $10 \mathrm{~min}$ in a $140 \mathrm{Na}_{0}{ }^{+}$solution) into low- $\mathrm{Na}^{+}(10 \mathrm{mM})$ solution. As shown in Table 2, this treatment caused a significant elevation in $\mathrm{Ca}_{\mathrm{i}}{ }^{2+}$ of both normal and CF cells. The level of $\mathrm{Ca}_{\mathrm{i}}{ }^{2+}$ achieved in response to exposure to low $\mathrm{Na}^{+}$solutions was not significantly different in $\mathrm{CF}$ cells as compared to normal cells $(p>0.1)$. Ten min of exposure to ouabain alone caused no change in $\mathrm{Ca}_{\mathrm{i}}{ }^{2+}$ in normal or $\mathrm{CF}$ nasal epithelia (Table 2).

We next tested the response of $\mathrm{CF}$ and normal cells to $\beta$ agonist exposure. In three experiments with quin2-loaded cells from normals, the level of $\mathrm{Ca}_{\mathrm{i}}{ }^{2+} 10 \mathrm{~min}$ after isoproterenol addition (106 $\pm 12 \mathrm{nM}, n=3$ ) was not different from the level of $\mathrm{Ca}_{\mathrm{i}}$ before addition (105 $\left.\pm 6 \mathrm{nM}, n=3\right)$. Similarly, in $\mathrm{CF}$ cells isoproterenol did not cause a significant increase in $\mathrm{Ca}_{\mathrm{i}}{ }^{2+}$ $(97 \pm 16 \mathrm{nM}, n=3)$ compared to $\mathrm{Ca}_{\mathrm{i}}{ }^{2+}$ levels before addition $(102 \pm 8 \mathrm{nM}, n=3)$.

To assure that we were not missing a $\mathrm{Ca}_{\mathrm{i}}{ }^{2+}$ response upon $\beta$ agonist stimulation due to buffering of $\mathrm{Ca}_{\mathrm{i}}{ }^{2+}$ by the relatively large intracellular levels of quin2, we repeated these studies using fura-2-loaded cells. Fura-2, recently introduced by Tsien and coworkers (20), has a 30 -fold increased fluorescence intensity as compared with quin 2 and can therefore be used at much lower loading levels. Typical results obtained using fura- 2 are shown in Figure 2 and summarized in Table II. As with the results with quin2-loaded cells, isoproterenol had no effect on $\mathrm{Ca}_{\mathrm{i}}{ }^{2+}$ when added to either fura-2-loaded normal or CF epithelial cells. Furthermore, forskolin, a direct activator of adenylate cyclase, had no effect on CF or normal epithelial cell $\mathrm{Ca}_{i}{ }^{2+}$. Comparable responses were observed in cells grown in the presence or absence of cholera toxin (data not shown).

Figure 3 demonstrates an increase in cell cAMP content in response to isoproterenol, measured in cells treated identically to those used in the $\mathrm{Ca}$ measurements. These data suggest that the lack of effect of isoproterenol on $\mathrm{Ca}_{i}$ is not due to the inability of isolated cells to respond to the agonist.

\section{DISCUSSION}

The central role of $\mathrm{Ca}^{2+}$ in regulation of epithelial transport processes has led many investigators to postulate a defect in cell $\mathrm{Ca}^{2+}$ homeostasis as being a central defect in CF. Studies of both secretory and absorptive epithelia have indicated that substantial species and organ variability exists but have generally led to the notion that raised cell $\mathrm{Ca}_{\mathrm{i}}{ }^{2+}$ levels activate, directly or indirectly, cell $\mathrm{Cl}^{-}$permeabilities (27), but decrease cell $\mathrm{Na}^{+}$permeability (7). Because CF respiratory epithelia exhibit a low basal $\mathrm{Cl}^{-}$ permeability but raised basal $\mathrm{Na}^{+}$permeability, a possible regulatory defect that would qualitatively account for these findings would be a low basal $\mathrm{Ca}_{\mathrm{i}}{ }^{2+}$ level $(1,3,4)$. Consequently, we 
Table 2. Cell $\mathrm{Ca}^{2+}$ levels $\left(\mathrm{Ca}_{i}^{2+}, n M\right)$ of normal and $\mathrm{CF}$ nasal epithelia measured with fura-2 before and during exposure to drugs and ion substitution*

\begin{tabular}{|c|c|c|c|c|c|c|}
\hline & \multicolumn{3}{|c|}{ Normal } & \multicolumn{3}{|c|}{$\mathrm{CF}$} \\
\hline & $n$ & Before & During & $n$ & Before & During \\
\hline $\begin{array}{l}\text { Ionomycin } \\
\left(10^{-5} \mathrm{M}\right)\end{array}$ & 3 & $140 \pm 20$ & $\geq 2000 \dagger$ & 3 & $143 \pm 21$ & $\geq 2000 \dagger$ \\
\hline $\begin{array}{l}\text { Ouabain } \\
\left(10^{-4} \mathrm{M}\right)\end{array}$ & 3 & $122 \pm 6$ & $112 \pm 11$ & 3 & $92 \pm 13$ & $92 \pm 13$ \\
\hline Low Na $\ddagger$ & & $112 \pm 11$ & $259 \pm 22 \uparrow$ & & $92 \pm 13$ & $238 \pm 44 \dagger$ \\
\hline $\begin{array}{l}\text { Isoproterenol } \\
\left(10^{-5} \mathrm{M}\right)\end{array}$ & 4 & $142 \pm 19$ & $144 \pm 21$ & 3 & $135 \pm 10$ & $132 \pm 11$ \\
\hline $\begin{array}{l}\text { Forskolin } \\
\left(10^{-6} \mathrm{M}\right)\end{array}$ & 4 & $138 \pm 22$ & $134 \pm 23$ & 3 & $119 \pm 14$ & $130 \pm 15$ \\
\hline
\end{tabular}

$*$ Values are mean $\pm \mathrm{SEM}, n=$ number of separate patient samples tested.

$\dagger$ Different than before value $(p<0.05)$.

$\ddagger$ The before condition is during ouabain.

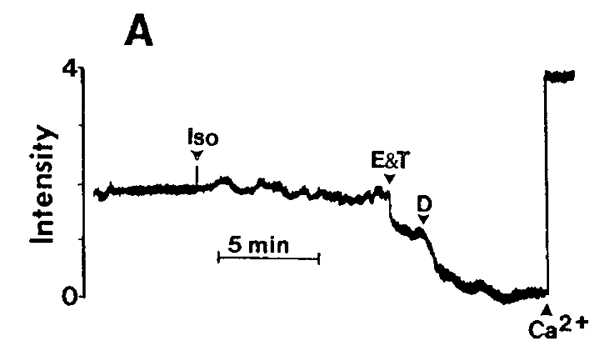

B

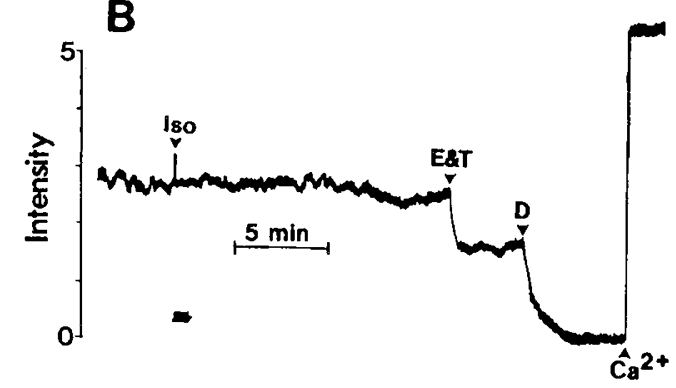

Fig. 2. Effect of isoproterenol on $\mathrm{Ca}_{\mathrm{i}}{ }^{2+}$ in fura-2-loaded nasal epithelial cells. $A$ depicts the changes in fluorescence intensity (excitation 340 $\mathrm{nm}$; emission $510 \mathrm{~nm}$ ) induced by sequential addition of reagents from a cell suspension from a normal subject. $B$ depicts the changes in fluorescence in a cell suspension from a CF patient. After a preincubation period, isoproterenol $\left(10^{-5} \mathrm{M}\right)$ was added to the cell suspension. $E \& T$, $D$, and $\mathrm{Ca}^{2+}$ are defined in the legend to Figure 1 . As seen in Table 2, the errors in these measurements are $\sim 5-15 \%$, thus an increase in $\mathrm{Ca}_{\mathrm{i}}$ of less than $\sim 50 \%$ would be undetectable. Additions are made through a hole drilled into the lid to the fluorometer. Thus the time resolution after addition of hormones is the mixing time which is less than $5 \mathrm{~s}$.

initially sought to measure basal $\mathrm{Ca}_{\mathrm{i}}{ }^{2+}$ and assess at least one transport process that contributes to the regulation of cell $\mathrm{Ca}_{\mathrm{i}}{ }^{2+}$, i.e. $\mathrm{Na}^{+}-\mathrm{Ca}^{2+}$ exchange.

We used the fluorescent calcium indicators quin 2 and fura-2 to monitor changes in $\mathrm{Ca}_{\mathrm{i}}{ }^{2+}$. These fluorescent indicators, introduced by Tsien and coworkers (18-20), are loaded into cells as the acetoxymethyl ester of quin2 or fura-2. Once inside the cell intracellular esterases cleave the acetoxymethyl ester to produce the free acid of the calcium chelator and by-products acetate and formaldehyde. Although this technique has become widely used

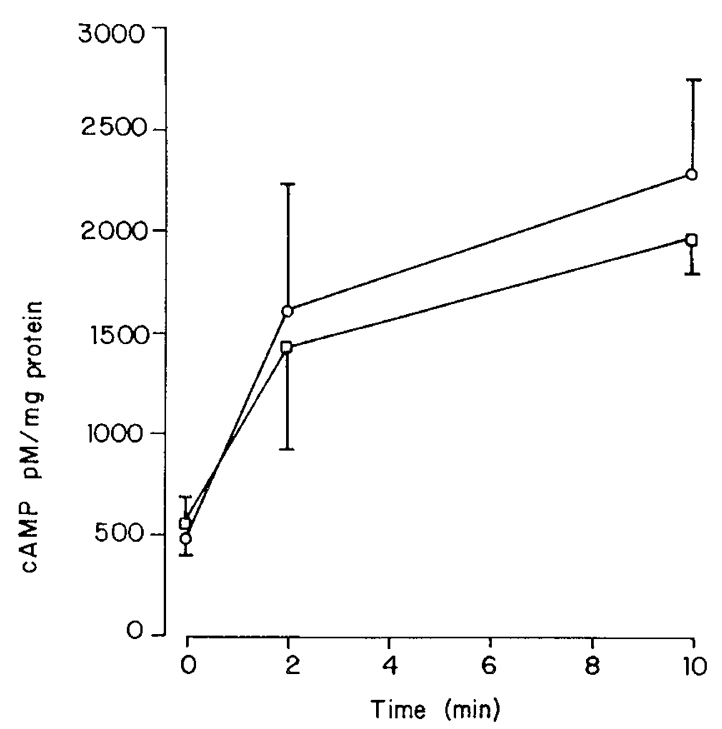

Fig. 3. Accumulation of cAMP in cultured nasal epithelial cells as a function of time after exposure to isoproterenol $\left(10^{-5} \mathrm{M}\right)$. Circles reflect data from cells of four CF subjects; squares reflect data from cells of five normal subjects; points reflect mean \pm SEM.

for $\mathrm{Ca}_{\mathrm{i}}{ }^{2+}$ measurements, potential problems with the technique exist. First, there are reports of adverse effects of the formaldehyde by-products (23). However, toxic effects appear rare. Second, quin 2 has a low fluorescence intensity and this property, coupled with cell autofluorescence, necessitates intracellular quin2 loadings in the $1.0 \mathrm{mM}$ range (23). This high level of loading is capable of buffering calcium transients $(19,23)$. We therefore repeated certain studies on fura-2-loaded cells because fura-2 has a higher fluorescent intensity and consequently can be used to measure $\mathrm{Ca}^{2+}$ when present at much lower intracellular levels. Finally, cell $\mathrm{Ca}^{2+}$ measurements are an average of ionized $\mathrm{Ca}^{2+}$ in cell compartments into which the dyes permeate. Preliminary optical microscopy indicates that fura-2 is not selectively concentrated in intracellular organelles in nasal epithelial cells.

As seen in Table 1 , basal $\mathrm{Ca}_{\mathrm{i}}{ }^{2+}$ levels measured with fura-2 were slightly higher than those measured with quin2. This discrepancy, which may reflect the decreased buffering with fura-2, has also been observed by others $(22,28)$. However, basal $\mathrm{Ca}_{i}{ }^{2+}$ levels measured with both indicators are well within the range of values reported by others using a variety of techniques in epithelial cells (28-30) as well as other tissues $(19,21,22,31)$. Impor- 
tantly, the $\mathrm{Ca}_{\mathrm{i}}{ }^{2+}$ values for CF compared to normal cells do not differ by either method.

$\mathrm{Na}^{+}-\mathrm{Ca}^{2+}$ exchange has been described in many cell types (32), including epithelial cells (33), and it appears to be involved in regulating basal $\mathrm{Ca}_{i}{ }^{2+}$ levels. We tested for the presence of a $\mathrm{Na}^{+}-$ $\mathrm{Ca}^{2+}$ exchange process in fura-2-loaded nasal epithelial cells by imposing ion gradients that would be expected to favor $\mathrm{Na}^{+}$in for $\mathrm{Ca}^{2+}$ out exchange. Lowering to $10 \mathrm{mM}$ the extracellular $\mathrm{Na}^{+}$ bathing $\mathrm{Na}^{+}$loaded cells resulted in a large increase in $\mathrm{Ca}_{\mathrm{i}}{ }^{2+}$, consistent with an exchange of extracellular $\mathrm{Ca}^{2+}$ for intracellular $\mathrm{Na}^{+}$(Table 2). The increase in $\mathrm{Ca}_{i}{ }^{2+}$ seen upon lowering extracellular $\mathrm{Na}^{+}$in $\mathrm{Na}^{+}$-loaded cells was similar in normal compared to CF nasal epithelial cells. This finding suggests that the response of the $\mathrm{Na}^{+}-\mathrm{Ca}^{2+}$ exchanger is similar in $\mathrm{CF}$ and normal epithelia.

We also sought to investigate the possible relationship between changes in cell $\mathrm{Ca}^{2+}$ activity and the observations that freshly excised normal tissues respond to isoproterenol or forskolin with $\mathrm{Cl}^{-}$secretion whereas $\mathrm{Na}^{+}$absorption but not $\mathrm{Cl}^{-}$secretion is accelerated in CF tissues (4). As recently reviewed by Rasmussen (34), the interactions between agonists that increase cAMP in cells and $\mathrm{Ca}^{2+}$ metabolism are complex. However, interactions between agonists that might be expected to raise cell cAMP levels (epinephrine) and $\mathrm{Ca}_{\mathrm{i}}{ }^{2+}$ levels have been reported in a variety of epithelia, including canine respiratory epithelia (30). Based on such studies, we reasoned that isoproterenol might act to increase cell $\mathrm{Ca}_{\mathrm{i}}{ }^{2+}$ in normal tissues, in concert with the induction of $\mathrm{Cl}^{-}$ secretion, but might decrease cell $\mathrm{Ca}_{\mathrm{i}}{ }^{2+}$ in $\mathrm{CF}$ tissues, in parallel with the increase in $\mathrm{Na}^{+}$absorption.

No changes in cell $\mathrm{Ca}_{\mathrm{i}}{ }^{2+}$ levels after exposure to isoproterenol or forskolin were detected in either CF or normal cells. The failure to detect a response is probably not related to a failure of cultured cells to respond to the addition of agonists for several reasons. First, cells treated in an identical protocol to that used for the $\mathrm{Ca}_{\mathrm{i}}{ }^{2+}$ measurements increased cell cAMP content in response to isoproterenol (Fig. 3 ). Second, the absence of change in $\mathrm{Ca}_{\mathrm{i}}{ }^{2+}$ after agonist exposure was also observed in cells cultured in the presence or absence of a culture media additive, cholera toxin, that may be expected to alter basal cAMP levels. Third, the bioelectric correlates of isoproterenol effects on ion transport of cultured CF and normal cells mimic those of fresh tissue, indicating that the linkage between cAMP accumulation and the functional response is not lost in these cells (35). Whereas it is conceivable that cell disaggregation influenced our findings, it appears more likely that substantial changes in $\mathrm{Ca}_{\mathrm{i}}{ }^{2+}$ levels in response to cAMP-accumulation are not a major feature in human respiratory epithelia. Consequently, the differing responses in CF and normal cells in responses to $\beta$-agonists may not be mediated by $\mathrm{Ca}^{2+}$-sensitive paths.

The role of $\mathrm{Ca}^{2+}$ in directly activating $\mathrm{Cl}^{-}$channels in normal and $\mathrm{CF}$ epithelial $\mathrm{Cl}^{-}$channels is unclear. Data from two reports of patch clamp studies of excised patches differ in their assessment of the role of bathing solution $\mathrm{Ca}^{2+}$ to activate $\mathrm{Cl}^{-}$channels $(5,6)$. Frizzell et al.(5) have also reported that $\mathrm{CF} \mathrm{Cl}^{-}$channels monitored in the on-cell patch mode are activated by the addition of $\mathrm{Ca}^{2+}$ ionophores. The activation of $\mathrm{CF} \mathrm{Cl}^{-}$channels by ionophore A23187 could either reflect 1) the elevation of cell $\mathrm{Ca}^{2+}$ levels from an abnormally low basal level, to a normal basal level or a supra-basal level required for activation or 2) an elevation of $\mathrm{Ca}_{\mathrm{i}}{ }^{2+}$ from a "normal" basal level to a supra-basal level required for activation. Our data that cell $\mathrm{Ca}_{\mathrm{i}}{ }^{2+}$ levels are comparable in $\mathrm{CF}$ and normal cells and that the ionophore response is roughly comparable in both cell populations would favor the latter interpretation.

Substantial variability is apparent in reports of total cell calcium values from a variety of CF versus normal cells. Our finding of comparable total cell calcium in CF and normals is in agreement with the findings in PMN (14) and lymphocytes (11) but is in disagreement with other reports describing raised total cell calcium levels in CF fibroblasts (9, 10), PMN (13), and lymphocytes (12). Somewhat more agreement has emerged from studies that have measured cell $\mathrm{Ca}_{\mathrm{i}}{ }^{2+}$ levels. Cell $\mathrm{Ca}_{\mathrm{i}}{ }^{2+}$ levels have been reported to be comparable in CF and normal RBC (15), PMN (14), and lymphocytes $(11,12)$. Our findings extend the observation from circulating blood elements that cell $\mathrm{Ca}_{\mathrm{i}}{ }^{2+}$ levels do not distinguish $\mathrm{CF}$ from normal cells to a target epithelium, i.e. the respiratory epithelium.

In summary, $\mathrm{Ca}_{\mathrm{i}}{ }^{2+}$ levels are similar in $\mathrm{CF}$ and normal respiratory epithelium. $\mathrm{Ca}_{\mathrm{i}}{ }^{2+}$ appears to be regulated in part by an $\mathrm{Na}^{+}-\mathrm{Ca}^{2+}$ exchange process that is expressed in cells from both $\mathrm{CF}$ and normal subjects. Changes in cell $\mathrm{Ca}_{\mathrm{i}}{ }^{2+}$ in response to agonists that modulate ion permeabilities do not appear to induce responses in cell $\mathrm{Ca}_{\mathrm{i}}{ }^{2+}$ that distinguish $\mathrm{CF}$ from normal. Consequently, paths that are sensitive to very small changes in cell $\mathrm{Ca}_{\mathrm{i}}{ }^{2+}$, or more likely regulatory paths or channels that may operate independently of $\mathrm{Ca}_{\mathrm{i}}{ }^{2+}$, appear important to the pathophysiology of CF.

Acknowledgments. The authors thank all CF Center Directors and personnel who assisted in obtaining samples used in this study.

\section{REFERENCES}

1. Knowles MR, Stutts MJ, Yankaskas JR, Gatzy JT, Boucher RC 1986 Abnormal respiratory epithelial ion transport in cystic fibrosis. Clin Chest Med 7:285-297

2. Quinton PM 1983 Chloride impermeability in cystic fibrosis. Nature 301:421422

3. Cotton CU, Stutts MJ, Knowles MR, Gatzy JT, Boucher RC 1987 Abnormal apical cell membrane in cystic fibrosis respiratory epithelium: a microelectrode analysis. J Clin Invest 79:80-85

4. Boucher RC, Stutts MJ, Knowles MR, Cantley LC, Gatzy JT $1986 \mathrm{Na}^{+}$ transport in cystic fibrosis (CF) respiratory epithelia: abnormal basal rate and response to adenylate cyclase activation. J Clin Invest 78:1245-1252

5. Frizzell RA, Rechkemmer G, Shoemaker RL 1986 Altered regulation of airway epithelial cell chloride channels in cystic fibrosis. Science 233:558-560

6. Welsh MJ, liedtke CM 1986 Chloride and potassium channels in cystic fibrosis airway epithelia. Nature 322:467-470

7. Taylor A, Windhager EE 1979 Possible role of cytosolic calcium and $\mathrm{Na}^{+}-\mathrm{Ca}^{2+}$ exchange in regulation of trans-epithelial sodium transport. Am J Physiol 236:F505-F512

8. Al-Bazzaz FJ 1986 Regulation of salt and water transport across airway mucosa. Clin Chest Med 7:259-272

9. Ceder O, Roomans G, Hosli P 1982 Increased calcium content in cultured fibroblasts from trisomy patients; comparison with cystic fibrosis fibroblasts. Scan Electron Microsc 2:723-730

10. Shapiro BL, Lam LF 1982 Calcium and age in fibroblasts from control subjects and patients with cystic fibrosis. Science 216:417-419

11. Grinstein S, Elden B, Clark CA, Buchwald M 1984 Is cytoplasmic $\mathrm{Ca}^{2+}$ in lymphocytes elevated in cystic fibrosis? Biochem Biophys Acta 769:204-244

12. Waller RC, Brattin WT, Dearborn DG 1984 Cytosolic free calcium concentra tion and intracellular calcium distribution in lymphocytes from cystic fibrosis patients. Life Sci 35:775-781

13. Cabrini G, DeTogni P 1985 Increased cytosolic calcium in cystic fibrosis neutrophils effect on stimulus-secretion coupling. Life Sci 36:1561-1567

14. Suter S, Lew PD, Ballanan J, Waldvogel FA 1985 Intracellular calcium handling in cystic fibrosis: normal cytosolic calcium and intracellular calcium stores in neutrophils. Pediatr Res 19:246-348

15. Waller RL, Johnson LR, Brattin WJ, Dearborn DG 1985 Erythrocyte cytosolic free $\mathrm{Ca}^{++}$and plasma membrane $\mathrm{Ca}^{++}$-ATPase activity in cystic fibrosis. Cell Calcium 6:245-64

16. Stutts MJ, Cotton CU, Yankaskas JR, Cheng E, Knowles MR, Gatzy JT, Boucher RC 1985 Chloride uptake into cultured airway epithelial cells from cytic fibrosis patients and normal individuals. Proc Natl Acad Sci USA 82:6677-6681

17. Wu R, Yankaskas J, Cheng E, Knowles MR, Boucher R 1985 Growth and differentiation of human nasal epithelial cells in culture: serum-free, hormone-supplemented medium and proteo-glycan synthesis. Am Rev Respir Dis 132:311-320

18. Tsien RY 1980 New calcium indicators and buffers with high selectivity against magnesium and protons: design, synthesis, and properties of prototype structures. Biochemistry 19:2396-2404

19. Tsien RY, Pozzan T, Rink TJ 1982 Calcium homeostasis in intact lymphocytes: cytoplasmic free $\mathrm{Ca}^{2+}$ monitored with a new, intracellularly trapped fluorescent indicator. J Cell Biol 94:325-334

20. Grynkiewicz G, Poenie GM, Tsien RY 1985 A new generation of $\mathrm{Ca}^{2+}$ indicators with greatly improved fluorescence properties. J Biol Chem 260:3440-3450

21. Murphy E, Jacob R, Lieberman M 1985 Cytosolic free calcium in chick heart cells: its role in cell injury. J Mol Cell Cardiol 17:221-231 
22. Jacob R, Murphy E, Lieberman M 1987 Free Calcium in isolated chick embryo heart cells measured using quin2 and fura-2. Am J Physiol 253:C337-C342 23. Rink TJ, Pozzan T 1985 Using quin 2 in cell suspensions. Cell Calcium 6:133144

24. Luckhoff, A 1986 Measuring cytosolic free calcium concentration in endothelial cells with indo-1: the pitfalls of using the ratio of two fluorescence intensities recorded at different wavelengths. Cell Calcium 7:233-248

25. Scallon M, Williams DA, Fay FS $1987 \mathrm{~A} \mathrm{Ca}^{2+}$ insensitive form of furaassociated with polymorphonuclear leukocytes. J Biol Chem 262:6308-6312

26. Lowry OH, Rosenbrough NJ, Farr AL, Randell RJ 1951 Protein measurements with Folin phenol reagent. J Biol Chem 193:265-275

27. Al-Bazzaz FJ, Jayaram T 1981 Ion transport by canine tracheal mucosa: effect of elevation of cellular calcium. across airway mucosa. Clin Chest Med 7:259-212

28. Jacobs WR, Mandel LJ 1986 Fura-2 measurements of cytosolic $\mathrm{Ca}^{2+}\left(\mathrm{Ca}_{\mathrm{f}}\right)$ in rabbit proximal tubules. Fed Proc 45:541
29. Lee CO, Taylor A, Windhauger 1986 Cytosolic calcium ion activity in epithelial cells of Necturis kidney. Nature 287:859-861

30. Welsh M, McCann JD 1985 Intracellular calcium regulates basolateral potassium channels in a chloride-secretory epithelium. Proc Natl Acad Sci USA $82: 8823-8826$

31. Tsien RY, Pozzan T, Rink TJ 1984 Measuring and manipulating cytosolic $\mathrm{Ca}^{2+}$ with trapped indicators. Trends Biochem Sci 9:263-266

32. Mullens LJ 1977 A mechanism for $\mathrm{Na}^{+}-\mathrm{Ca}^{2+}$ transport. J Gen Physiol 70:681695

33. Gmaj P, Murer H, Kinne R 1979 Calcium in transport across plasma membranes isolated from rat kidney cortex. Biochem $\mathbf{J}$ 136:71-76

34. Rasmussen H 1986 The calcium messenger system. N Engl J Med 314:1094 1101

35. Cotton CU, Yankaskas JR, Knowles MR, Gatzy JT, Boucher RC 1988 Microelectrode analysis of cultured normal and cystic fibrosis nasal epithelial cells. J Physiol (in press) 